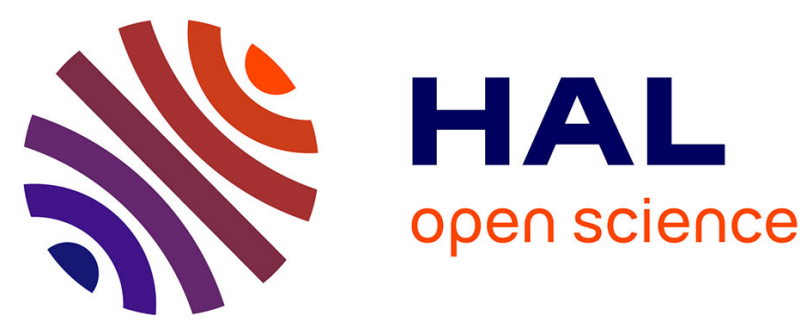

\title{
Friction stir welding of AZ31 magnesium alloy rolled sheets: Influence of processing parameters
}

Loreleï Commin, Myriam Dumont, Jean-Eric Masse, Laurent Barrallier

\section{To cite this version:}

Loreleï Commin, Myriam Dumont, Jean-Eric Masse, Laurent Barrallier. Friction stir welding of AZ31 magnesium alloy rolled sheets: Influence of processing parameters. Acta Materialia, 2009, 57 (2), pp.326-334. 10.1016/j.actamat.2008.09.011 . hal-01059733

\section{HAL Id: hal-01059733 https://hal.science/hal-01059733}

Submitted on 1 Sep 2014

HAL is a multi-disciplinary open access archive for the deposit and dissemination of scientific research documents, whether they are published or not. The documents may come from teaching and research institutions in France or abroad, or from public or private research centers.
L'archive ouverte pluridisciplinaire HAL, est destinée au dépôt et à la diffusion de documents scientifiques de niveau recherche, publiés ou non, émanant des établissements d'enseignement et de recherche français ou étrangers, des laboratoires publics ou privés. 


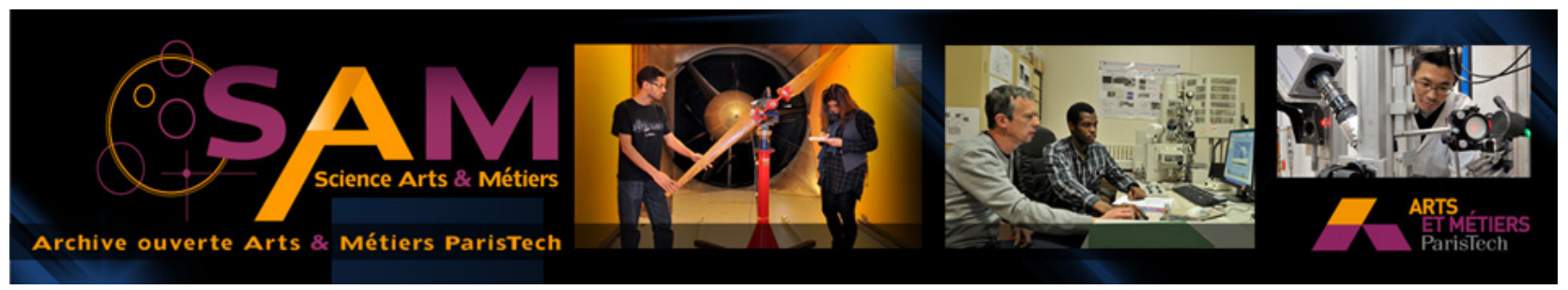

\section{Science Arts \& Métiers (SAM)}

is an open access repository that collects the work of Arts et Métiers ParisTech researchers and makes it freely available over the web where possible.

This is an author-deposited version published in: http://sam.ensam.eu

Handle ID: .http://hdl.handle.net/10985/8435

\section{To cite this version :}

Loreleï COMMIN, Myriam DUMONT, Jean-eric MASSE, Laurent BARRALLIER - Friction stir welding of AZ31 magnesium alloy rolled sheets: Influence of processing parameters - Acta Materialia - Vol. 57, n², p.326-334 - 2009 


\title{
Friction stir welding of AZ31 magnesium alloy rolled sheets: Influence of processing parameters
}

\author{
L. Commin ${ }^{\mathrm{a}, *}$, M. Dumont ${ }^{\mathrm{b}}$, J.-E. Masse ${ }^{\mathrm{a}}$, L. Barrallier ${ }^{\mathrm{a}}$ \\ ${ }^{a}$ MecaSurf, Arts et Metiers ParisTech, 2 cours des Arts et Metiers, 13617 Aix en rovence, France \\ ${ }^{\mathrm{b}}$ IM2NP, Paul Cezanne University, Marseille, France
}

\begin{abstract}
The temperature evolution during friction stir welding (FSW) and the resulting residual stresses of AZ31 Mg alloy were studied to get a better understanding of the mechanisms involved in this process. The relationship between the processing parameters, the heat and plastic deformation produced and the resulting microstructure and mechanical properties was investigated. Increasing the shoulder diameter or the tool rotation speed or decreasing the welding speed produced an increase in the heat generated during the process and then promoted grain growth. The temperature distribution on the advancing side and on the retreating side differed, and stress levels were higher on the retreating side. The grain size heterogeneity produced by FSW was not the prevailing cause of failure.
\end{abstract}

Keywords: Friction stir welding; Magnesium alloys; Thermo-mechanical analysis; Microstructure; Mechanical properties

\section{Introduction}

The need for weight reduction in the aircraft industry has raised interest in using magnesium alloys to replace aluminium alloys in some structural and mechanical parts. Indeed, magnesium alloy densities are 36\% lower than aluminium alloys, leading to a high strength to weight ratio. Although they have limited workability at room temperature owing to their hexagonal close packed structure, they have good formability at high temperature. Magnesium alloys are also attractive owing to their electromagnetic interference shielding properties [1] and their recyclability.

With their increasing application, having a reliable joining process is required, but welding magnesium alloys still faces many challenges. Magnesium alloys can be joined using a wide variety of processes, but conventional processes have exhibited some disadvantages such as a large heat affected zone (HAZ), porosity, evaporative loss of the alloying elements and high residual stresses [2].

\footnotetext{
${ }^{*}$ Corresponding author. Tel.: +33 442938154; fax: +33 442938115 .

E-mail address: lorelei.commin@ensam.fr (L. Commin).
}

Friction stir welding (FSW) is an alternative method, which could overcome the above disadvantages. Indeed, FSW is performed below the melting temperature of the material to be welded, and it produces pore-free joints and smaller temperature gradients than conventional arc processes [3]. However, the FSW weldability of magnesium alloys is still an issue.

During FSW, heat is generated by the friction between the tool and the workpiece and by the plastic deformation occurring around the tool. An understanding of the temperature distribution is necessary, as it influences the weld microstructure and its resulting mechanical properties. Temperature measurements using embedded thermocouples were previously performed for aluminium alloys [4-7]. They did not observe any temperature variation between the advancing and retreating side [4]. They concluded that the heat generated was influenced mainly by the shoulder diameter and that an increase in applied pressure and tool rotation rate/ welding speed ratio $(W / V)$ resulted in a higher temperature [4,7]. Arbegast and Hartley [8] established a relationship for aluminium alloys between the maximum 
welding temperature and the processing parameters $(W, V)$.

The aim of this study is to investigate the processing parameters and the properties of the welds obtained for magnesium alloys and to discuss the potential for using FSW in the aircraft industry to join magnesium alloys.

Mechanical and thermal processes induced during FSW were studied in order to get a better understanding of the process for magnesium alloys, and then to optimize the processing parameters for controlling the microstructure and weld properties.

\section{Experimental}

\subsection{Material and FSW processing parameters used}

The base material analysed was AZ31-O magnesium alloy.

Friction stir welds were processed using 2-mm-thick hotrolled sheets produced by Salzgitter Magnesium Technologie $\mathrm{GmbH}$.

Several FSW routes were carried out. The facility used for the first route was an EADS-IWF hydraulic MTS Istir PDS machine with a 4-mm-diameter screwed pin and a 10-mmdiameter scroll shoulder tool. "Bead on plate" welds were produced, for the sake of simplicity, to determine the effect of welding speed and rotation rate on the weld microstructure.

Further trials were made at EADS-IWG to investigate the effect of processing temperature and processing stress on the microstructure and mechanical properties. Butt welds were produced, and temperature and strain measurements were performed during the process for four welding conditions (1000 rpm/200 $\mathrm{mm} \mathrm{min}^{-1}, 1300 \mathrm{rpm} / 300 \mathrm{~mm} \mathrm{~min}^{-1}, 1400$ $\mathrm{rpm} / 700 \mathrm{~mm} \mathrm{~min}^{-1}$ and $600 \mathrm{rpm} / 2000 \mathrm{~mm} \mathrm{~min}^{-1}$ ). The facility used was an ESAB Superstir machine with a 5-mmdiameter threaded pin and a 13-mm concave shoulder tool

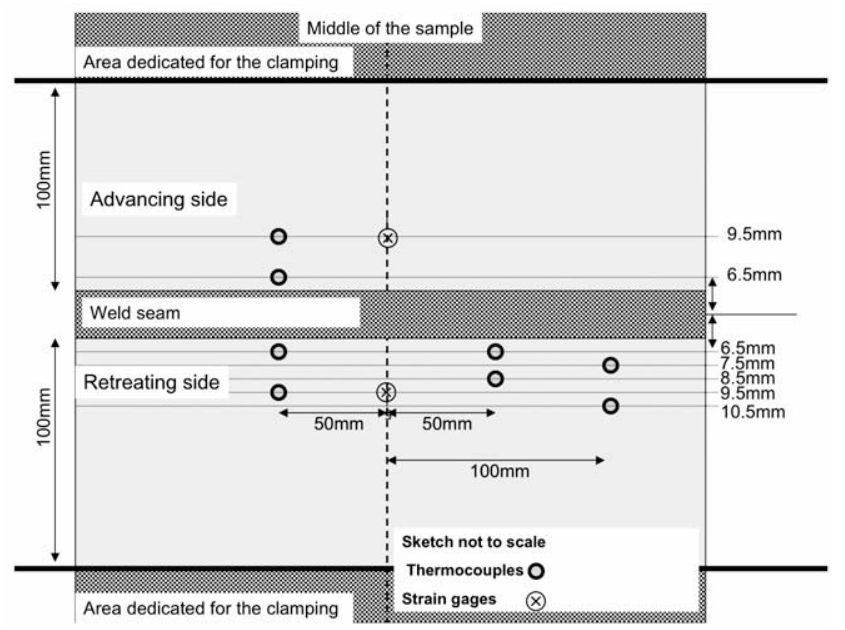

Fig. 1. Strain and temperature measurement locations during FSW process. and with a 5-mm-diameter threaded pin and a 10-mm-diameter concave shoulder tool.

The applied pressure $(F)$ for butt welds was in the range $6.5-9 \mathrm{kN}$ except for the weld processed at $2000 \mathrm{~mm} \mathrm{~min}^{-1}$, where a $22 \mathrm{kN}$ load was applied.

Temperature measurements during welding were made using K-type thermocouples embedded in the sample mid-thickness. Strain gauges were used to determine the residual stresses during welding. The measurement locations are described in Fig. 1.

\subsection{Weld characterization}

Visual inspection and radiography techniques were used to characterize the welded samples' defects.

\subsection{Microstructural characterization}

Optical microscopy was used to determine the grain size evolution, while scanning electronic microscopy (SEM) and transmission electronic microscopy (TEM) were used to observe the precipitation state.

Polished samples were etched with an acetopicral solution $(0.4 \mathrm{~g}$ picric acid, $13 \mathrm{ml}$ ethanol, $3 \mathrm{ml}$ glacier acetic acid and $3 \mathrm{ml}$ boiled water). They were observed using a Leitz Aristomet optical microscope and a JEOL JMS 6400 SEM.

TEM samples were made from 2-mm-thick plates. Samples $1 \mathrm{~cm}^{2}$ were ground down to a thickness between 100 and $200 \mu \mathrm{m}$ using several silicon carbide polishing papers. They were then electrochemically polished in a Struers Tenupol-3 jet polisher at a temperature $<10{ }^{\circ} \mathrm{C}$ with a polishing voltage of $14 \mathrm{~V}$. The polishing solution was $10 \% \mathrm{HCl}, 90 \%$ butoxy-2-ethanol by volume. TEM observations were performed using a FEI TECNAI G ${ }^{2}$.

Image analysis was performed using Image $\mathbf{J}$ software. Grain sizes were determined using the equivalent diameters calculated, and the standard deviations obtained were used to determine error bars.

\subsection{X-ray diffraction}

Residual stresses were determined by lattice parameter displacement measurement on the $\{104\}$ diffracting plane using a SEIFERT MZ6TS diffractometer with $\mathrm{CrK} \alpha$ radiation $(\lambda=0.228975 \mathrm{~nm})$ and a PSD detector. Measurements were performed across the weld line on the top surface of the weld. The gauge volume was determined with a $2 \times 2 \mathrm{~mm}$ tape mask. The $\sin ^{2} \Psi$ method was used to determine the residual stresses.

\subsection{Mechanical characterization}

Tensile tests were performed at $4 \mathrm{~mm} \mathrm{~min}^{-1}$ strain rate using a Instron $5800 \mathrm{R}$ machine with a $100 \mathrm{kN}$ load cell. Dumb-bell specimens were mechanically polished using a $400 \mathrm{SiC}$ paper before testing to allow a consis- 


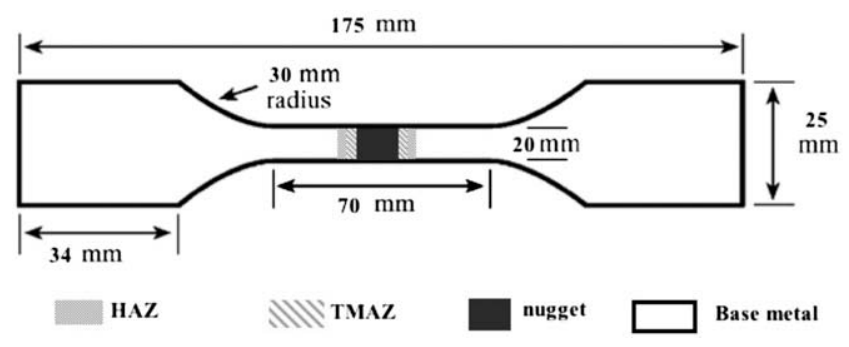

Fig. 2. Dumb-bell specimen specification.

tent comparison. Fig. 2 illustrates the tensile specimen geometry.

\section{Results}

\subsection{Determination of the process window}

"Bead on plate" samples were used to determine the FSW process window for AZ31 magnesium alloy (Fig. 3). The welds obtained that did not present any porosity, any crack and that exhibited a flash size $<2 \mathrm{~mm}$ were defined as "sound welds".

The visual aspect of the welds, characterized by limited flash and tunnelling phenomena occurring (Figs. 4 and 5)

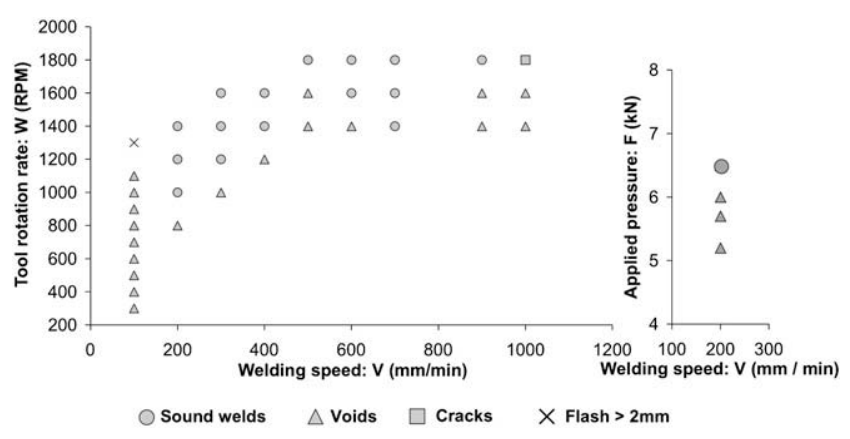

Fig. 3. AZ31 process window and defects observed. was improved with increasing load applied $(F)$ (see Fig. 3), weld speed $(V)$ and rotation rate $(W)$ (see Fig. 4).

\subsection{Microstructure of friction stir welds grain size}

The AZ31 friction stir weld microstructure consists in three different zones, clearly identified: the nugget, the TMAZ and the HAZ/base metal, as no difference in grain size between HAZ and base metal could be observed.

When studying the influence of the welding parameters on the grain size, several conclusions can be established. First, it appears that a large microstructure gradient is obtained in the TMAZ at low $(W, V)$ values, whereas this gradient is smoother at high $(W, V)$ values (Fig. 6).

Moreover, in the weld nugget, relatively small grains are observed at low $(V, W)$. Increasing $W$ leads to an increase in grain size and in grain size dispersion. Increasing $V$ induces a decrease in grain size. At high $W$, there is no more influence of the welding speed on the grain size. Increasing the shoulder diameter induces an increase in the grain size (Fig. 7). This is mainly due to the relationship between welding parameters and the temperature reached during welding, which was exhibited previously. Indeed, increasing the shoulder diameter or the tool rotation speed $(W)$ or decreasing the welding speed $(V)$ produces an increase in the heat generated during the process and promotes grain growth.

\subsection{Microstructure of friction stir welds precipitation}

The intragranular precipitation study indicated that the (Al, Mn) phase was not undergoing any transformation during FSW (Fig. 8). Indeed, nanoscale precipitates identified as $\mathrm{Al}_{8} \mathrm{Mn}_{5}$ using energy dispersive spectroscopy, did not dissolve during FSW and were not modified by changing the welding parameters. During the FSW process, the maximum temperature achieved does not exceed the melting temperature, which is $610^{\circ} \mathrm{C}$ for this alloy [9]. This is consistent with the phase diagram [10], which indicates that

\section{Constant V $=100 \mathrm{~mm} / \mathrm{min}$}

Increasing W (RPM)
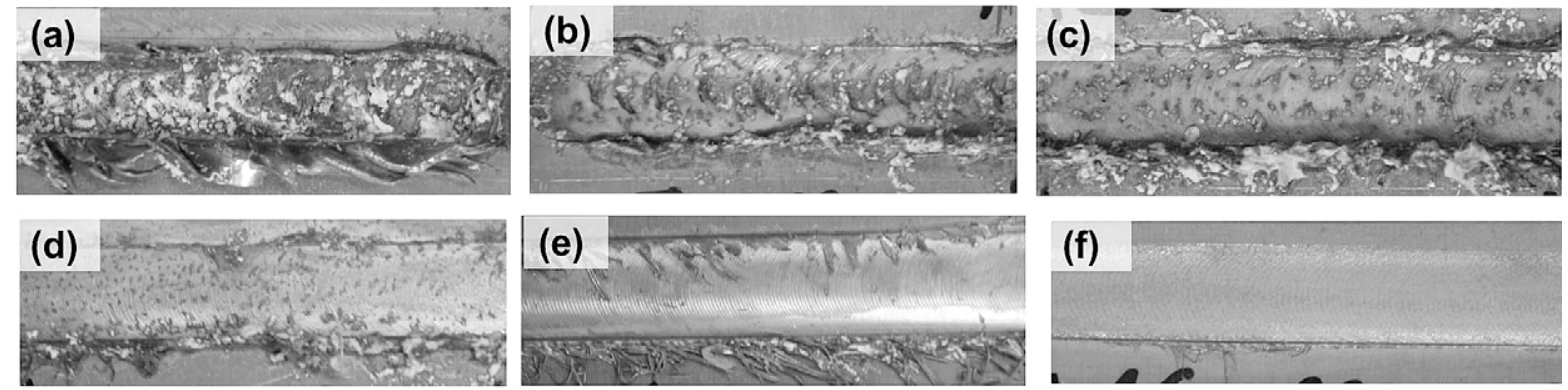

Constant W = 1600 RPM

Increasing V ( $\mathrm{mm} / \mathrm{min})$

Fig. 4. Digital images of the superficial aspect of several "bead on plate" AZ31 welds: (a) $W=400 \mathrm{rpm}, V=100 \mathrm{~mm} \mathrm{~min}{ }^{-1}$; (b) $W=700 \mathrm{rpm}$, $V=100 \mathrm{~mm} \mathrm{~min}^{-1}$; (c) $W=900 \mathrm{rpm}, \quad V=100 \mathrm{~mm} \mathrm{~min}^{-1}$; (d) $W=1600 \mathrm{rpm}, \quad V=400 \mathrm{~mm} \mathrm{~min}^{-1}$; (e) $W=1600 \mathrm{rpm}, \quad V=600 \mathrm{~mm} \mathrm{~min}-1$; (f) $W=1600 \mathrm{rpm}, V=1000 \mathrm{~mm} \mathrm{~min}^{-1}$. 


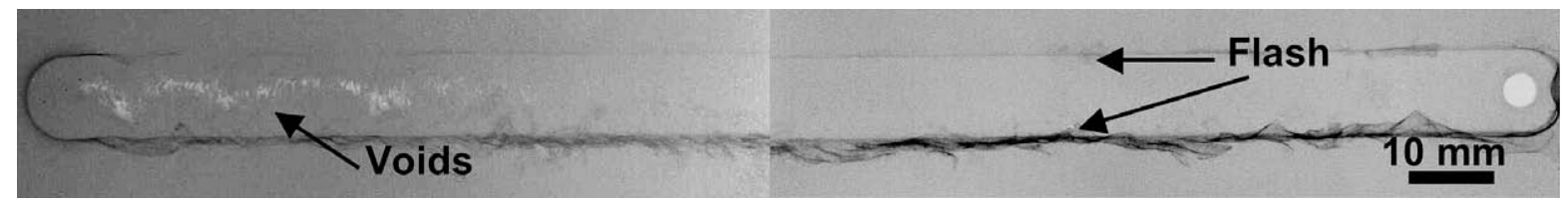

Fig. 5. Radiography of AZ31 welds $V=200 \mathrm{~mm} \mathrm{~min}^{-1}, W=800-1400 \mathrm{rpm}$. The bright features correspond to lack of material in the weld region, and the dark features correspond to the flash.
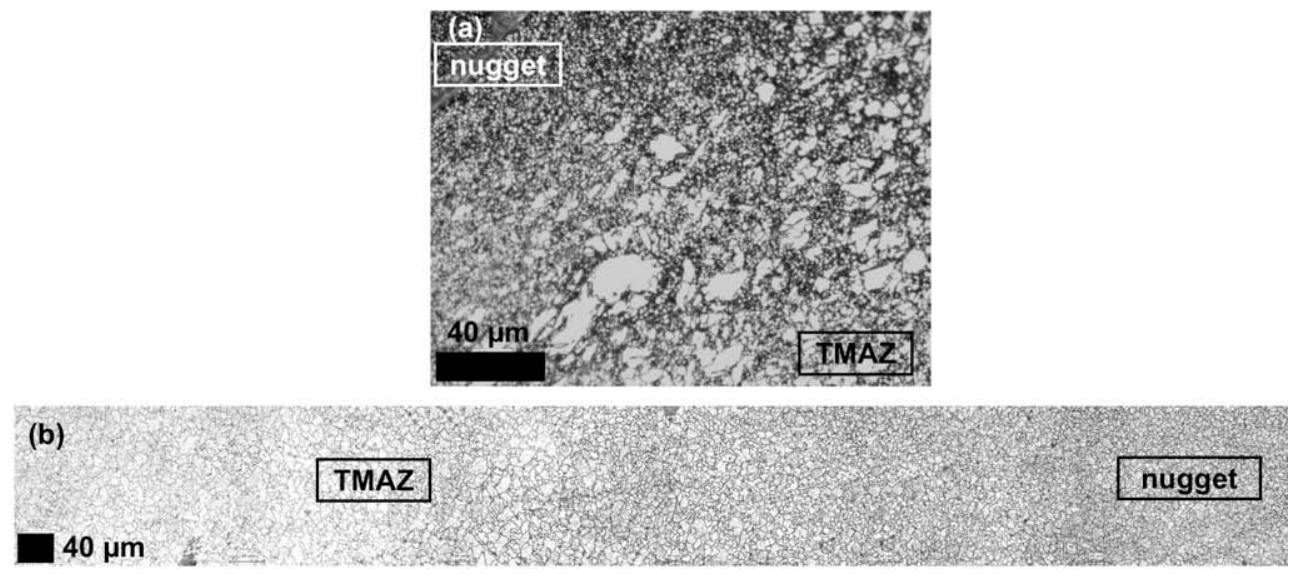

Fig. 6. Grain size evolution in the TMAZ for "bead on plate" FSW (tool $4 \mathrm{~mm} \mathrm{pin} / 10 \mathrm{~mm}$ shoulder): (a) $600 \mathrm{rpm}, 100 \mathrm{~mm} \mathrm{~min}{ }^{-1}$; (b) $1800 \mathrm{rpm}$, $1000 \mathrm{~mm} \mathrm{~min}^{-1}$.
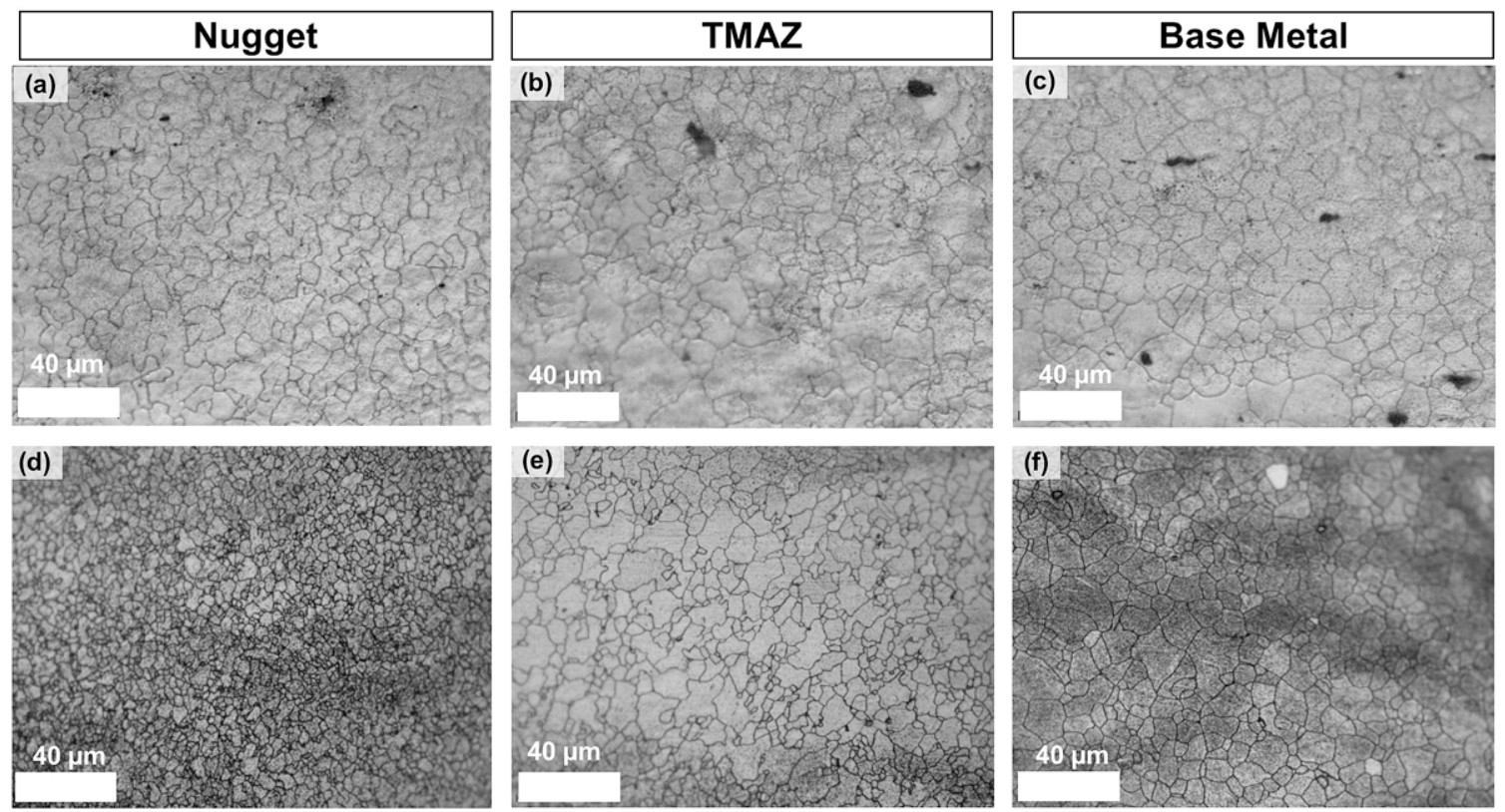

Fig. 7. Grain size evolution with shoulder diameter for $1000 \mathrm{rpm}, 200 \mathrm{~mm} \mathrm{~min}{ }^{-1}$ butt FSW: (a-c) $13 \mathrm{~mm}$ shoulder diameter; (d-f) $10 \mathrm{~mm}$ shoulder diameter.

$\mathrm{Al}_{8} \mathrm{Mn}_{5}$ phase dissolves above $610{ }^{\circ} \mathrm{C}$ for this alloy chemical composition.

\subsection{Thermal history}

The welding parameters have a major influence on the heat generated. Indeed, increasing the tool shoulder diameter, increasing the rotation rate and decreasing the welding speed contribute to increasing the process heat generation. Temperature measurements were performed during the FSW process to investigate the influence of processing parameters such as welding speed, tool rotation rate and shoulder diameter on the temperature generation. 

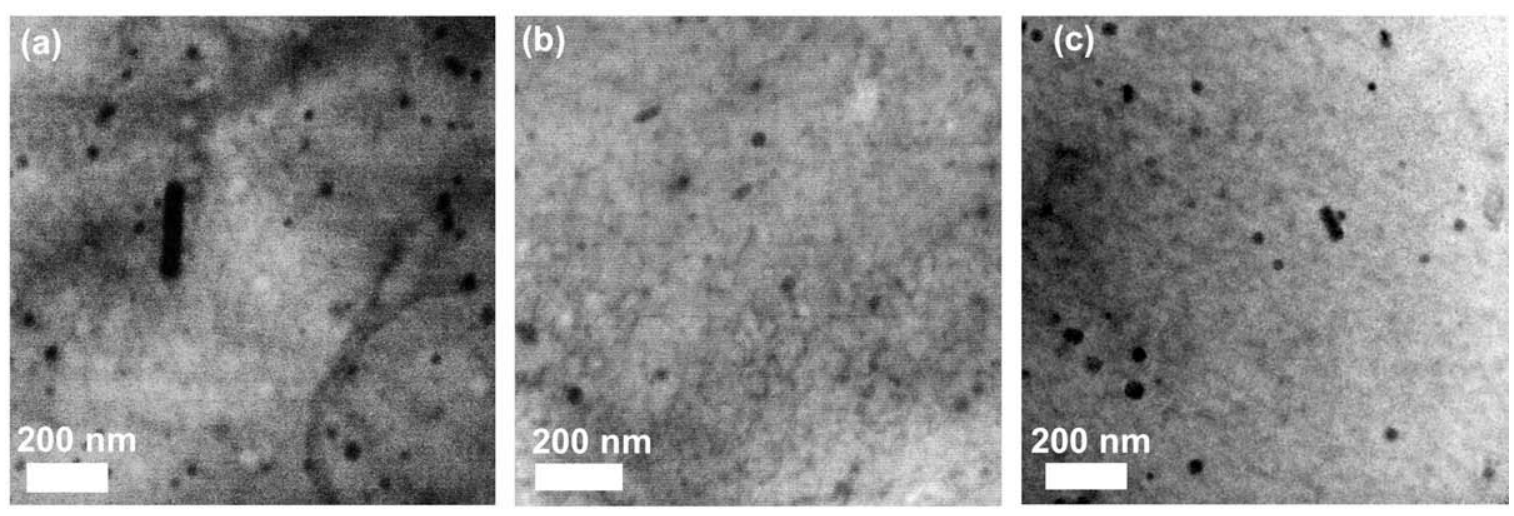

Fig. 8. Intragranular precipitation evolution in the butt weld nugget (tool $5 \mathrm{~mm}$ pin/10 $\mathrm{mm}$ shoulder): (a) $\left(600 \mathrm{rpm}, 2000 \mathrm{~mm} \mathrm{~min}{ }^{-1}\right)$; (b) (1000 rpm, $200 \mathrm{~mm} \mathrm{~min}^{-1}$ ); (c) base metal.

Temperature measurements were taken at several locations, and the peak temperatures (Fig. 9) measured were taken into account for further analysis. The temperature is uniform along the weld length, and the temperature dissipation is similar for each weld studied. The temperatures measured on the advancing side and on the retreating side were different (Fig. 9). This is due to the heat input generated by the plastic deformation.

\subsection{Residual stress analysis}

Residual stress analysis was performed using the strain gauge data recorded during welding and by XRD after welding. Stress calculation is detailed in Ref. [11]. Fig. 10 shows the evolution of the equivalent stress and the hydrostatic stress during welding. The strain gauges overcharged (peak values) when the tool passed across, and then they reached a constant residual stress level. X-ray diffraction (XRD) was carried out after welding at the same measurement locations ( $\pm 4 \mathrm{~mm}$ from the weld seam). A comparison of the results (Fig. 10) indicates that there is a good agreement between the XRD and strain gauge results, both showing that higher stress levels are induced on the retreating side.

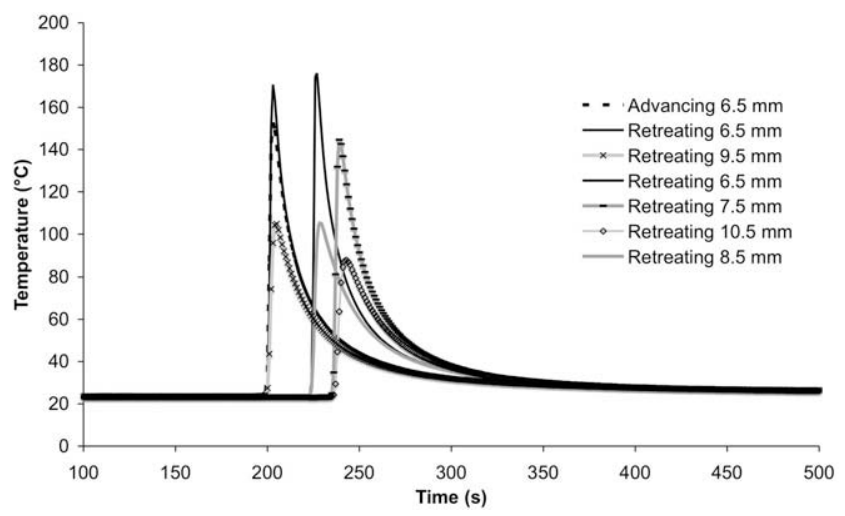

Fig. 9. Temperature measurements during FSW butt welding $(600 \mathrm{rpm}$, $2000 \mathrm{~mm} \mathrm{~min}^{-1}$ ).

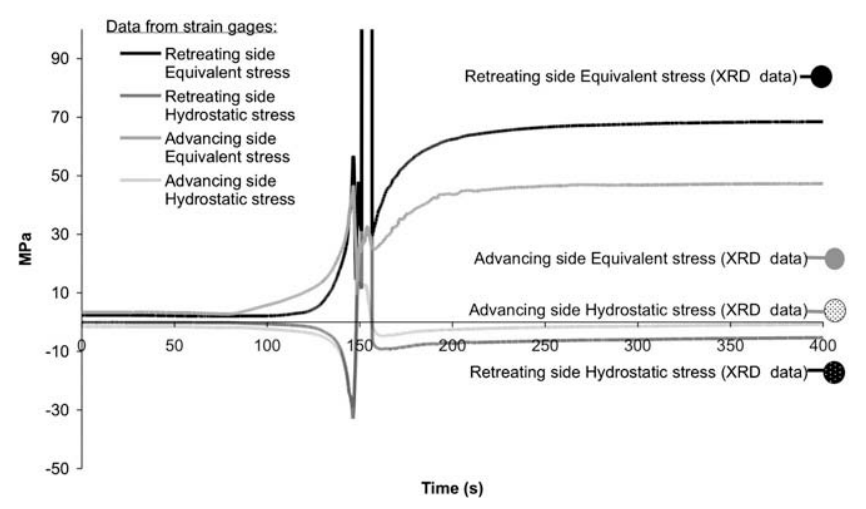

Fig. 10. Comparison between the stress evolutions during welding (strain gauges) and XRD results for FSW (1000 rpm, $200 \mathrm{~mm} \mathrm{~min}^{-1}$, tool $5 \mathrm{~mm}$ pin/13 mm shoulder).

\subsection{Microhardness profiles of friction stir welds}

The influence of the welding parameters on the microhardness evolution is characterized in Fig. 11. Using high $(W / V)$, induced a very low variation in microhardness val-

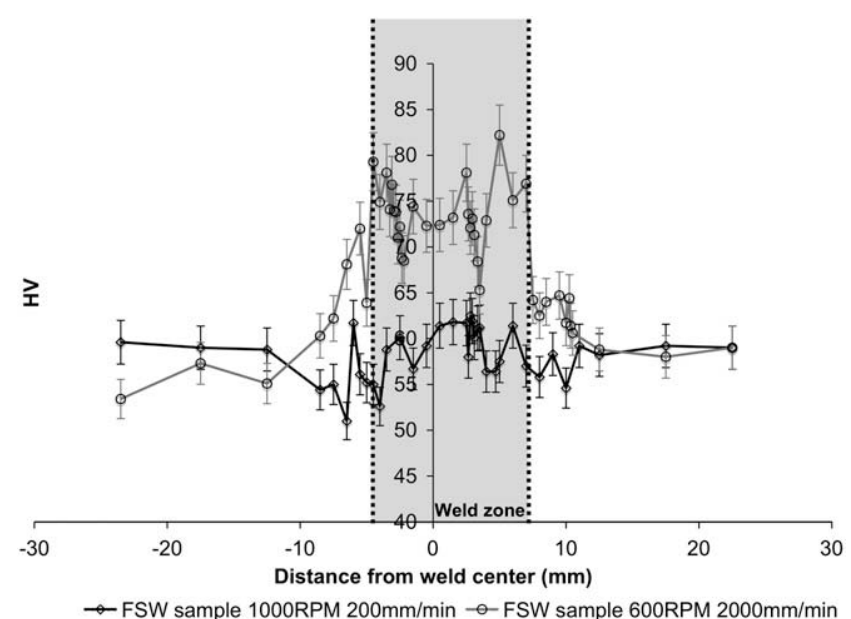

Fig. 11. Evolution of microhardness $(0.98 \mathrm{~N}, 15 \mathrm{~s})$ in FSW. 
ues compared with the base metal ones, whereas using low $(W / V)$ induced an increase in the weld zone.

\subsection{Tensile testing of friction stir welds}

For each welding parameter studied, the tensile mechanical properties of the butt welds are similar and far lower than the base metal ones (Fig. 12). This is consistent with the study by Lim et al. [12], who also observed a reduction in tensile properties after FSW and no significant influence of the welding parameters.

The failure occurred each time in the TMAZ/nugget transition on the advancing side except for the $(1400 \mathrm{rpm}$, $700 \mathrm{~mm} \mathrm{~min}^{-1}$ ) butt weld, which failed on the retreating

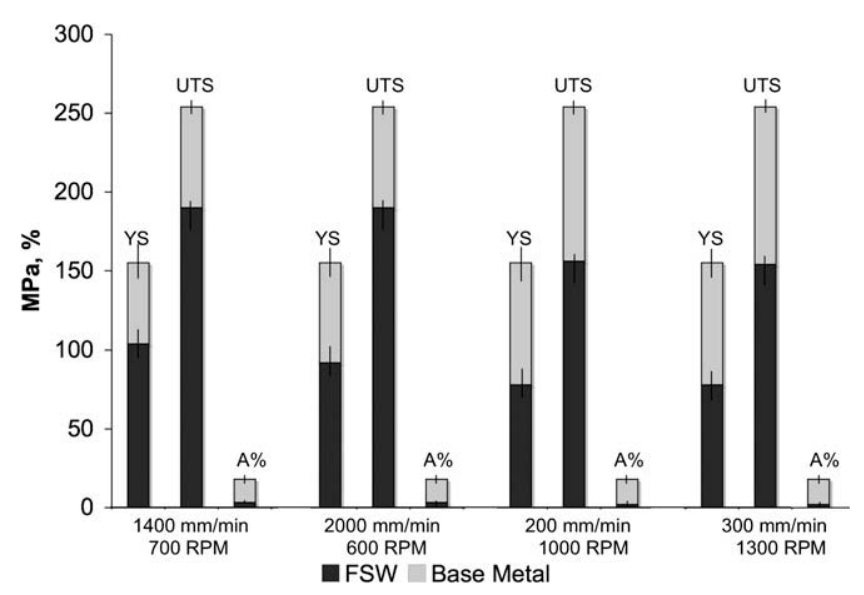

Fig. 12. Tensile properties of friction stir welds. side of the weld. An additional crack was created on the back surface of the opposite TMAZ/nugget transition. The fracture surface exhibited three different zones (Fig. 13) presenting ductile and brittle fracture features. Brittle fracture occurred on the top surface of the weld. This fracture pattern is consistent with other studies and characteristic of AZ31 friction stir welds [12-13].

\section{Discussion}

\subsection{Relationship between processing parameters and resulting microstructure}

The peak temperature was plotted vs the measurement location for each welding parameter investigated (Fig. 14). Increasing the shoulder diameter led to an increase in the peak temperature (Fig. 14) and a modification in the heat dissipation. Indeed, the area that has undergone friction is larger with increasing shoulder diameter. The heat generated is larger for the same $W$ and $V$ parameters.

Fitting each curve was performed using [14]

$T=R T+T_{x 0} \operatorname{erfc}\left(\frac{x}{2 \sqrt{\frac{K}{\rho^{C}} t}}\right)$

where $R T$ is room temperature, $T_{x 0}$ is the temperature of the heat source, $x$ is the distance from the heat source, $K$ is the thermal conductivity $\left(=96 \mathrm{~W} \mathrm{~m}^{-1} \mathrm{~K}^{-1}\right)[9], \rho$ is the alloy density $\left(=1900 \mathrm{~kg} \mathrm{~m}^{-3}\right), C$ is the specific heat $\left(=1040 \mathrm{~J} \mathrm{~kg}^{-1} \mathrm{~K}^{-1}\right)[9], t$ is the time. The temperature val-
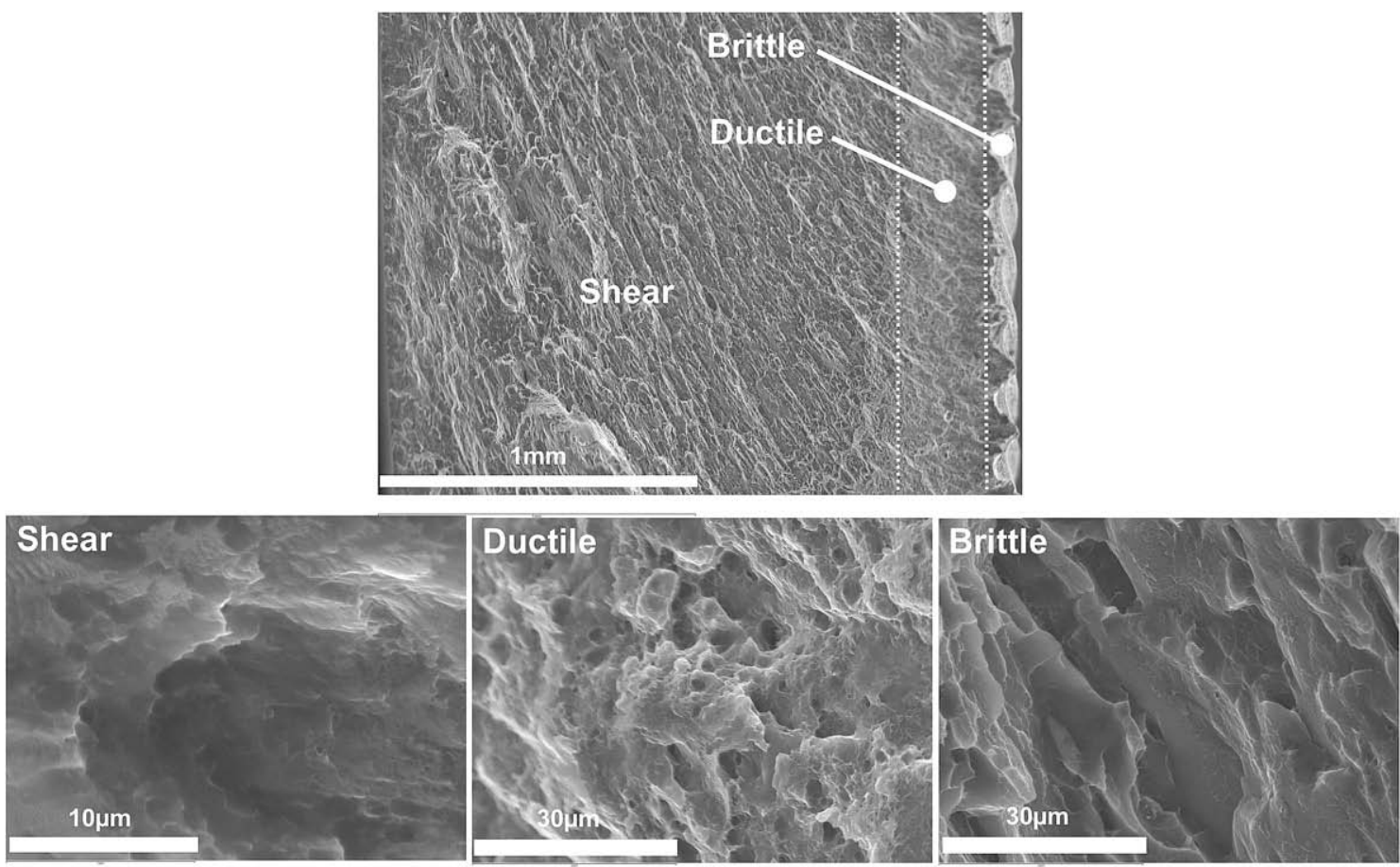

Fig. 13. Typical fractography of friction stir welds failure $\left(1000 \mathrm{rpm}, 200 \mathrm{~mm} \mathrm{~min}{ }^{-1}\right)$. 


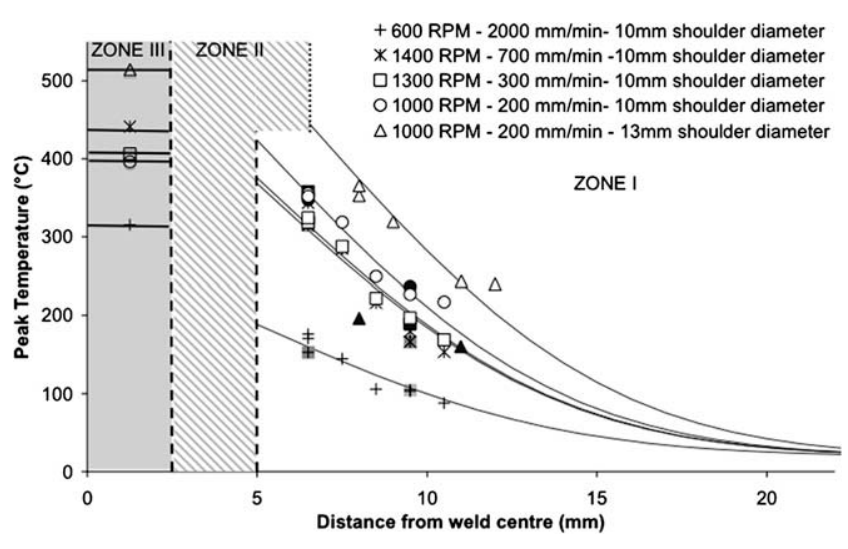

Fig. 14. Evolution of the peak temperatures measured. The filled features correspond to the advancing side data. The data in Zone III correspond to the nugget temperatures calculated using the Chang model.

ues obtained are valid in Zone I (Fig. 14). The temperature distribution below the shoulder (Zone II) cannot be described by this behaviour, as it does not take into account the shoulder contribution to heat generation. Tang et al. [4] demonstrated that temperature distribution within the stirred zone is relatively uniform. Thus, one can assume that the temperature in Zone III is uniform.

In the literature relative to AZ31 friction stir processing $[15,16]$, empirical relationships were established to calculate the maximum processing temperature (in this paper called "nugget temperature") from the grain size obtained in the nugget. Chang et al. [15,17] developed a model for ultra fine grain structure (submicron grains) and Watanabe et al. [16] developed a model for 3- to $100-\mu \mathrm{m}$ grain size.

Watanabe model $: \frac{D_{\text {nugget }}}{D_{\text {initial }}}=10^{3} Z^{-1 / 3}$

Chang model $: \ln \left(D_{\text {nugget }}\right)=9.0-0.27 \ln Z$

with $D_{\text {nugget }}$ the grain size in the nugget, $D_{\text {initial }}$ the base metal grain size, and $Z$ the Zener-Hollomon parameter

The Zener-Hollomon parameter can be described by

$Z=\dot{\varepsilon} \exp \left(\frac{Q}{R T}\right)$

where $Q$ is the activation energy for lattice diffusion $\left(135 \mathrm{~kJ} \mathrm{~mol}^{-1}[18]\right), R$ is the gas constant, $T$ is the nugget temperature, and the strain rate [17]

$\dot{\varepsilon}=\frac{\frac{W}{2} \cdot 2 \pi R_{\text {nugget }}}{D_{\text {nugget }}}$ where $R_{\text {nugget }}$ and $D_{\text {nugget }}$ are the effective radius and depth of the recrystallized zone.

The grain size in the nugget was determined for each $(W, V)$ parameter studied (Table 1$)$. The nugget temperatures were then calculated using Chang and Watanabe models (Table 1). The temperature at the shoulder edge was determined from the experimental data using the fitting function described above.

The experimental data grain sizes are in the $1.5-5 \mu \mathrm{m}$ range, in-between the application range of the Chang and Watanabe models. A better description is given in the present case by the Chang model. By comparing the nugget temperatures calculated using the Chang model and the corresponding experimental temperature at the shoulder edge for each welding parameter studied, one can calculate the mean difference between these temperatures. The nugget temperature is then $\sim 232.5 \pm 57.6{ }^{\circ} \mathrm{C}$ higher than the temperature at the edge of the shoulder.

Increasing the $W / V$ ratio leads to an increase in the nugget temperature, as found in previous studies $[4,7]$. Arbegast and Hartley [8] established a relationship for aluminium alloys between the nugget temperature and the processing parameters $(W, V)$ :

$\frac{T}{T_{\mathrm{m}}}=K\left(\frac{W^{2}}{V \cdot 10^{4}}\right)^{\alpha}$

where $T_{\mathrm{m}}$ is the alloy melting point, and the constants $\alpha, K$ vary between 0.04 and 0.06 and 0.65 and 0.75 , respectively.

Using this relationship for magnesium alloys, good agreement was found with the following parameters (Fig. 15): $T_{\mathrm{m}}=610^{\circ} \mathrm{C}$ the alloy melting point [9], and the constants $\alpha=0.0442$ and $K=0.8052$.

\subsection{Relationship between processing parameters and weld quality}

The process window determination revealed that there was a minimum welding speed $\left(200 \mathrm{~mm} \mathrm{~min}^{-1}\right)$ to achieve sound welds. At low welding speed, the intense stirring causes an increase in the trapped particles content, which can be responsible for the weld defects. Then, above this threshold value, when using low rotation rates, the frictional heat generated is not sufficient to promote material flow, and then inner voids all along the weld are created (tunnelling phenomenon). But an excessive increase in rotation rate results in cracks appearing due to the expelling of material. These results are consistent with Nakata [19], who described the same phenomena for AZ61 alloys.

Table 1

Nugget grain size, nugget temperature and experimental temperature at the shoulder edge for each FSW butt weld

\begin{tabular}{llllll}
\hline$W(\mathrm{rpm})$ & $V\left(\mathrm{~mm} \mathrm{~min}^{-1}\right)$ & $D_{\text {nugget }}(\mu \mathrm{m})$ & $T_{\text {Chang }}\left({ }^{\circ} \mathrm{C}\right)$ & $T_{\text {Watanabe }}\left({ }^{\circ} \mathrm{C}\right)$ & $T_{\text {shoulder edge experimental }}\left({ }^{\circ} \mathrm{C}\right)$ \\
\hline 600 & 2000 & 1.66 & 315.6 & 456.9 & 168.5 \\
1000 & 200 & 3.74 & 396.5 & 560.4 & 404.0 \\
1300 & 300 & 3.84 & 406.5 & 575.3 & 355.6 \\
1400 & 700 & 5.15 & 441.2 & 619.8 & 348.3 \\
\hline
\end{tabular}




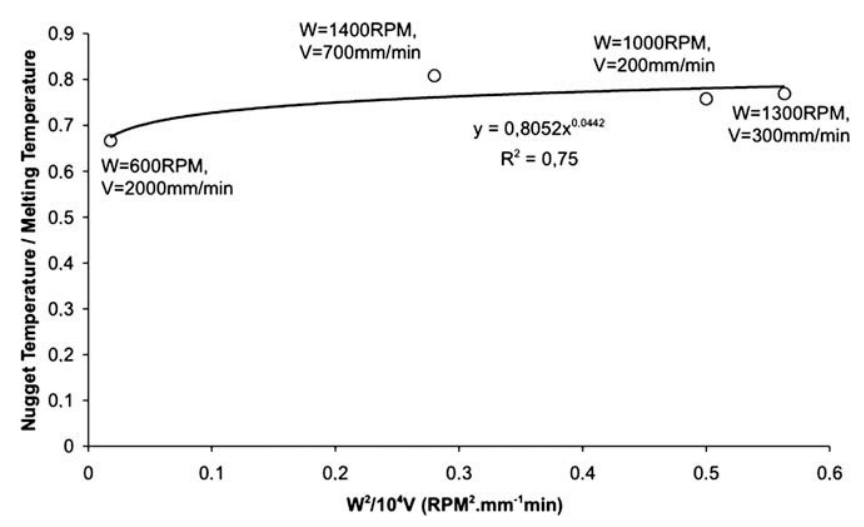

Fig. 15. Nugget temperature vs $W^{2} / V$ ratio.

Using the relationship determined previously to calculate the nugget temperature for each "bead on plate" weld (Fig. 16), one observes that there is a minimum temperature of $417{ }^{\circ} \mathrm{C}$ needed to achieve sound welds. This is in contradiction to the fact that sound butt welds had been achieved at $315^{\circ} \mathrm{C}$. So the relationship found for butt welds is not applicable for "bead on plate" welds. This indicates also that the processing temperature is not the only parameter to consider when defining sound welds.

\subsection{Relationship between microstructure and mechanical properties}

As the hardening effect of the nanosized precipitates is not modified during FSW, the hardness evolution is related mainly to the grain size evolution observed. Microstructure and microhardness experimental analysis enables the hardening effect due to grain size evolution across the weld to be studied. The mean values of grain size and microhardness in each weld zone and the corresponding standard deviation were used. In aluminium alloy FSW, the Hall-Petch relationship is generally followed [20-22]. In this study, it is observed that the grain size influence on hardness and on the yield strength does not follow the Hall-Petch relationship (Fig. 17). This is due to the influence of the dislocation density [23] and residual stress variations within the weld.

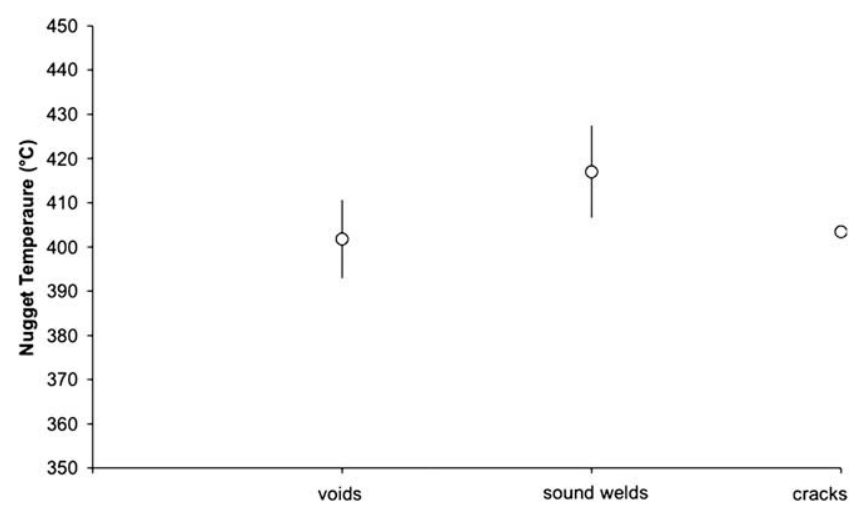

Fig. 16. Nugget temperature vs weld quality.

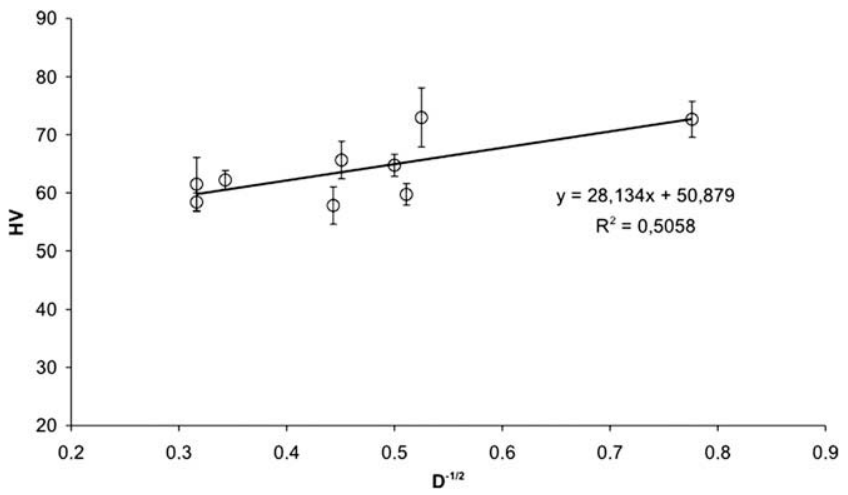

Fig. 17. Evolution of microhardness with grain size in FSW.

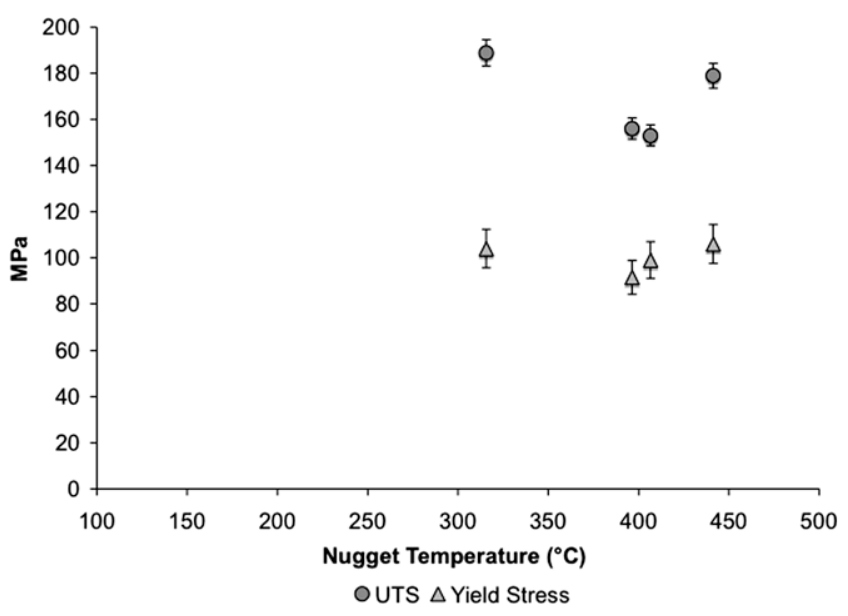

Fig. 18. Evolution of UTS and yield stress with the nugget temperature during butt welding.

The residual stress values reached in AZ31 using FSW are higher those obtained using the laser welding process [24]. Owing to the low temperature gradients observed in FSW compared with fusion welding processes, such as laser welding, lower residual stresses would be expected. But, FSW requires far more rigid clamping, which causes residual stress generation during cooling. The residual stress level obtained after FSW aluminium alloys is in the same range $(<100 \mathrm{MPa}$ [25-27]), but it corresponds to $30-60 \%$ of FSW yield stress and $20-50 \%$ of base metal yield stress [25], whereas in AZ31 it corresponds to $66-76 \%$ of FSW yield stress and $46 \%$ of base metal yield stress.

The influence of nugget temperature on mechanical properties is shown in Fig. 18. The larger grain refinement, and therefore larger microstructure heterogeneity, induced at low nugget temperature showed the best mechanical properties. This indicates that the grain size heterogeneity is not the prevailing factor for FSW failure.

\section{Conclusions}

The study of the thermal and mechanical processes involved in FSW leads to several conclusions: 
1. The process window for welding AZ31 2-mm plates was determined: Sound welds were achieved with $V>200 \mathrm{~mm} \mathrm{~min}^{-1}, \quad W^{2} / V>4000 \mathrm{rpm}^{2} \operatorname{min~mm}^{-1}$ (i.e., nugget temperature $>417^{\circ} \mathrm{C}$ ).

2. Weld quality was improved with increase in load applied, weld speed and rotation rate.

3. From temperature measurements at the shoulder edge, nugget temperature can be calculated.

4. A relationship between processing parameters and nugget temperature for AZ31 magnesium alloys was determined: $\frac{T}{T_{\mathrm{m}}}=K\left(\frac{W^{2}}{V \cdot 10^{4}}\right)^{\alpha}$

- with $T_{\mathrm{m}}=610^{\circ} \mathrm{C}$ the alloy melting point [9], and the constants $\alpha=0.0442$ and $K=0.8052$.

5. The temperature distribution is uniform along the weld length, whereas it is asymmetric between the advancing side and the retreating side, owing to the heat input generated by the plastic deformation.

6. Stress levels observed are higher on the retreating side.

7. Grain growth is observed with an increase in the processing parameters that promote heat generation.

8. The grain size evolution is consistent with the models developed, taking into account the strain rate and the processing temperature.

9. The AZ31 intragranular precipitation was not modified by FSW.

10. FSW induced lower tensile mechanical properties for this hot-rolled base metal alloy.

11. The grain size heterogeneity is not the prevailing factor for FSW failure.

\section{Acknowledgements}

This work was performed as a part of AEROMAG Project "Aeronautical Application of Wrought Magnesium" (Project No. AST4-CT-2005-516152), which was supported by the European Union. The authors wish to thank Tommy Brunzel, Jürgen Silvanus and Elke Hombergsmeier of EADS-IWG, Ottobrunn for friction stir welding and Wahib Saikaly and Thomas Neisius of CP2M laboratory, Paul Cezanne University, Marseille, for TEM investigation.

\section{References}

[1] Aghion E, Brofin B. Mater Sci Forum 2000.

[2] Cao P, Ma Q, St. John DH. Scripta Mater 2006;54:1853.

[3] Wang YN, Chang CI, Lee CJ, Lin HK, Huang JC. Scripta Mater 2006;55:637.

[4] Tang W, Guo X, McClure JC, Murr LE. J Mater Process Manufact Sci 1998;7:163.

[5] Kwon YJ, Saito N, Shigematsu I. J Mater Sci Lett 2002;21:1473.

[6] Sato YS, Urata M, Kokawa H. Metall Mater Trans A 2002;33: 625.

[7] Hashimoto T, Jyogan S, Nakata K, Kim YG, Ushio M. In: Proceedings of the first international symposium on friction stir welding, Thousand Oaks, CA, USA; June 14-16, 1999.

[8] Arbegast WJ, Hartley PJ. In: Proceedings of the fifth international conference on trends in welding research, Pine Mountain, GA, USA; June 1-5, 1998.

[9] Supplier data (Magnesium Elektron).

[10] Laser T, Nürnberg MR, Janz A, Hartig C, Leitzig D, Schmid-Fetzer R, et al. Acta Mater 2006;54:3033.

[11] Vishay micro-measurements technical note TN-515, Document Number 11065, Revision 25 March 2008.

[12] Lim S, Kim S, Lee CG, Yim CD, Kim SJ. Metall Mater Trans A 2005;36:1609.

[13] Afrin N, Chen DL, Cao X, Jahazi M. Mater Sci Eng A 2008;472: 179 .

[14] Adda Y. Philibert J La diffusion des solides. Paris: Presses universitaires de France Ed.; 1966.

[15] Chang CI, Du XH, Huang JC. Scripta Mater 2007;57:209.

[16] Watanabe H, Tsutsui H, Mukai T, Ishikawa H, Okanda Y, Kohzu M, et al. Mater Trans 2001;42:1200.

[17] Chang CI, Lee CJ, Huang JC. Scripta Mater 2004;51:509.

[18] Forst HJ, Ashby MF. Pergamon Press: Oxford; 1982. p. 21, 44.

[19] Nakata K, Kim YG, Ushio M. Trans JWRI 2002;31:141.

[20] Hirata T, Oguri T, Hagino H, Tanaka T, Chung SW, Takigawa Y, et al. Mater Sci Eng A 2007;456:344.

[21] Sato Y, Urata M, Desrayaud C, Montheillet D, Allehaux D, Driver JH. Mate Sci Eng A 2003;354:298.

[22] Jones MJ, Heurtier P, Hagino H, Tanaka T, Chung SW, Takigawa Y, et al. Mater Sci Eng A 2007;456:344.

[23] Esparza JA, Davis WC, Trillo EA, Murr LE. J Mater Sci Lett 2002;21:917.

[24] Coelho RS, Kotska A, Pinto H, Riekehr S, Koçak M, Pyzalla AR. Mater Sci Eng A 2007.

[25] Donne CD, Lima E, Wegener J, Pyzalla A, Buslaps T. Un: Proceedings of the third international symposium on friction stir welding, Kobe, Japan; September 27-28, 2001.

[26] Wang XL, Feng Z, David S, Spooner S, Hubbard CS. In: Proceedings of the sixth international conference on residual stresses (ICRS-6), IOM Communications, Oxford, UK; 2000. p. 1408-20.

[27] Peel M, Steuwer A, Preuss M, Withers PJ. Acta Mater 2003:4791. 